\title{
SCREENING OF INDUCERS FOR LACCASE PRODUCTION BY LENTINULA EDODES IN LIQUID MEDIUM
}

\author{
José Renato P. Cavallazzi ${ }^{1 *}$; Catarina M. Kasuya ${ }^{1}$; Marcos A. Soares ${ }^{2}$ \\ ${ }^{1}$ Laboratório de Patologia Florestal e Genética da Interação Planta-Patógeno, Universidade Federal de Viçosa, Viçosa, MG, \\ Brasil; ${ }^{2}$ Departamento de Microbiologia, Universidade Federal de Viçosa, Viçosa, MG, Brasil
}

Submitted: September 27, 2004; Returned to authors for corrections: April 22, 2005; Approved: November 22, 2005

\begin{abstract}
Laccases are enzymes involved in lignin degradation and are produced by various organisms. Due to their low substrate specificity their potential to be used in biotechnological applications has received attention. The addition of laccase inducers to the culture medium of microorganisms can enhance laccase production and facilitate its purification and utilization. The aim of this study was to investigate the effect of some compounds as laccase inducers in cultures of Lentinula edodes (shiitake). First, it was selected a culture medium suitable for laccase production by shiitake using two levels of $\mathrm{N}(2.6$ and $26 \mathrm{mM})$ and seven levels of $\mathrm{Cu}(0,50,100,150,200,250$ and $300 \mu \mathrm{M})$. The medium with $2.6 \mathrm{mM} \mathrm{N}$ and $250 \mu \mathrm{M} \mathrm{Cu}$ was found to provide the highest laccase activity. To the selected medium it were added gallic acid $(1 \mathrm{mM})$, catechol $(1 \mathrm{mM})$, ammonium tartrate $(55 \mu \mathrm{M})$, hydroxybenzoic acid $(1 \mathrm{mM})$ and vanillin $(1 \mathrm{mM})$. The two first compounds completely inhibited laccase activity and a 30 day time course experiment was carried out with the remaining compounds. Only cultures with ammonium tartrate exhibited laccase activity higher than control cultures, reaching $251 \mathrm{U} /$ $\mathrm{mL}$ of extract after 30 days. A native-PAGE was performed and showed only one band, suggesting that no isozyme was produced.
\end{abstract}

Key words: Laccase, shiitake, laccase inducers

\section{INTRODUCTION}

Laccases (benzenediol: oxygen oxidoreductase; E.C. 1.10.30.2) are multi-copper containing proteins that are widely distributed among fungi $(23,25)$ but are also found in bacteria (1), insects (22) and plants (15). These enzymes are involved in lignin degradation (15) and their low substrate specificity allows them to oxidize a wide range of compounds, which makes them suitable for biotechnological and environmental applications (20). However, high amounts of the enzyme are needed for these applications, as well as to study and understand its properties and role in lignin biodegradation. In this way, researches have been developed in order to increase laccase production by searching for new sources of it $(16,17)$ and by screening for inducers of laccase production by microorganisms, like aminoacids (8), aromatic compounds (10), plant extracts (2) and copper $(9,20)$. The white rot fungus shiitake (Lentinula edodes (Berk.) Pegler) is one of the most produced edible mushrooms in the world (5) and the most commercially important mushroom grown on wood (24). In the literature, little information about shiitake laccase inducers is available. In this way, the aim of this work was to study the effect of some compounds on the vegetative growth and laccase production by shiitake grown in liquid medium.

\section{MATERIALS AND METHODS}

\section{The fungus}

Lentinula edodes (isolate UFV52) was obtained from the culture collection of the Federal University of Viçosa, Minas Gerais State, Brazil. The fungal culture was maintained through

*Corresponding Author. Mailing address: BIOAGRO - Laboratório de Patologia Florestal e Genética da Interação Planta-Patógeno, Universidade Federal de Viçosa, Viçosa. 36570-000, Viçosa, MG, Brasil. Tel: (+5531) 3899-1110, Fax: (+5531) 3899-2573. E-mail: jrpcavallazzi@yahoo.com.br 
periodic transfer onto potato dextrose agar (PDA) plates, at $25^{\circ} \mathrm{C}$ and $\mathrm{pH}$ 5.0.

\section{Selection of medium for laccase production \\ Liquid medium cultivation}

In order to select the best medium for laccase production, two concentrations of nitrogen and seven concentrations of copper were tested. One agar disk taken from the active borders of PDA cultures were transferred to Erlenmeyer flasks $(125 \mathrm{~mL})$ containing $60 \mathrm{~mL}$ of the following liquid medium (in $\mathrm{g} . \mathrm{L}^{-1} ; \mathrm{pH}$ 5.0): glucose (10; SIGMA, St. Louis, USA), $\mathrm{KH}_{2} \mathrm{PO}_{4}(0.2$; SIGMA, St. Louis, USA), $\mathrm{MgSO}_{4} .7 \mathrm{H}_{2} \mathrm{O}$ (0.05; SIGMA, St. Louis, USA), $\mathrm{CaCl}_{2}(0.013$; MERK, Darmstadt, Germany), $\mathrm{MnSO}_{4} .5 \mathrm{H}_{2} \mathrm{O}$ (0.5; SIGMA, St. Louis, USA), $\mathrm{NaCl}$ (0.5, MERK, Darmstadt, Germany), $\mathrm{FeCl}_{3}$ (1.0; MERK, Darmstadt, Germany), $\mathrm{ZnSO}_{4} .7 \mathrm{H}_{2} \mathrm{O}$ (0.1; MERK, Darmstadt, Germany), AlK( $\left.\mathrm{SO}_{4}\right)_{2}$ (0.01; SIGMA, St. Louis, USA), $\mathrm{H}_{3} \mathrm{BO}_{3}\left(0.01\right.$; SIGMA, St. Louis, USA) and $\mathrm{NaMoO}_{4} \cdot 2 \mathrm{H}_{2} \mathrm{O}(0.01$; SIGMA, St. Louis, USA). The nitrogen was added as L-asparagine (26 mM N; SIGMA, St. Louis, USA) for high nitrogen (HN) and $\mathrm{NH}_{4} \mathrm{NO}_{3}$ (2.6 mM N; SIGMA, St. Louis, USA) for low nitrogen (LN) media. Copper sulphate was added to the flasks 3 days after inoculation to achieve concentrations of $0,50,100,150,200,250$ or $300 \mu \mathrm{M}$ of copper added as $\mathrm{CuSO}_{4}$ (SIGMA, St. Louis, USA). The flasks were incubated at $25^{\circ} \mathrm{C}$ in the dark, without shaking. After 14 days inoculation laccase activity was determined and mycelium was collected to determine the dry weight matter.

\section{Laccase activity assessment in the filtrate}

The liquid cultures were filtered using Millipore membranes $(0.45 \mu \mathrm{m})$ and the filtrates were used for enzyme assays which were performed in triplicate. Laccase activity was determined by the oxidation of 2,2'-azino-bis (3-ethylbenzthiazoline-6sulfonic acid) (ABTS; SIGMA, St. Louis, USA) at $37^{\circ} \mathrm{C}$ according to Buswell et al. (4). The reaction mixture $(1 \mathrm{~mL})$ contained 600 $\mu \mathrm{L}$ enzyme extract, $300 \mu \mathrm{L}$ sodium acetate buffer $\mathrm{pH} 5.0(0.1 \mathrm{M})$ and $100 \mu \mathrm{LABTS}$ solution $(1 \mathrm{mM})$. Oxidation was followed via the increase in absorbance at $420 \mathrm{~nm}\left(\varepsilon_{420}=36,000 \mathrm{M}^{-1} \cdot \mathrm{cm}^{-1}\right)$. One unit of enzyme activity was defined as the amount of enzyme oxidizing $1 \mathrm{mmol}$ of ABTS per minute.

\section{Screening for compounds increasing laccase activity}

After the selection of the best medium for laccase activity, five compounds were investigate for their capacity to increase enzyme activity in L. edodes cultures: gallic acid (1mM; SIGMA, St. Louis, USA), catechol, (1 mM; SIGMA, St. Louis, USA), ammonium tartrate $(55 \mu \mathrm{M}$; SIGMA, St. Louis, USA), 3 hidroxybenzoic acid ( $1 \mathrm{mM}$; SIGMA, St. Louis, USA) and vanillin (1mM; SIGMA, St. Louis, USA). One control treatment was used without the addition of any putative inducer. The compounds were sterilized by filtration using a Millipore membrane $(0.45 \mu \mathrm{m})$ and added aseptically into de flasks. Eighteen days after inoculation the laccase activity was determined.

\section{RESULTS}

\section{Selection of medium for laccase production}

Two weeks after inoculation the LN cultures with $250 \mu \mathrm{M}$ $\mathrm{CuSO}_{4}$ exhibited the highest laccase activity (Fig. 1A). The highest laccase activity in $\mathrm{HN}$ flasks was detected in $100 \mu \mathrm{M}$ treatment. The average of shiitake mycelium dry weight after 18 days of cultivation is presented in Fig. 1B. As expected, shiitake growing in HN cultures presented higher dry weight values than shiitake cultivated in LN flasks with the exception of cultures growing in $50 \mu \mathrm{M} \mathrm{CuSO}_{4}$. The culture medium with $\mathrm{LN}$ and 250 $\mu \mathrm{M} \mathrm{CuSO}_{4}$ was used in the experiments described above.

\section{Screening for compounds increasing laccase activity}

After 18 days of cultivation, the shiitake cultures growing in flasks with catechol and gallic acid did not show any laccase activity (data not shown) thus those compounds were not used

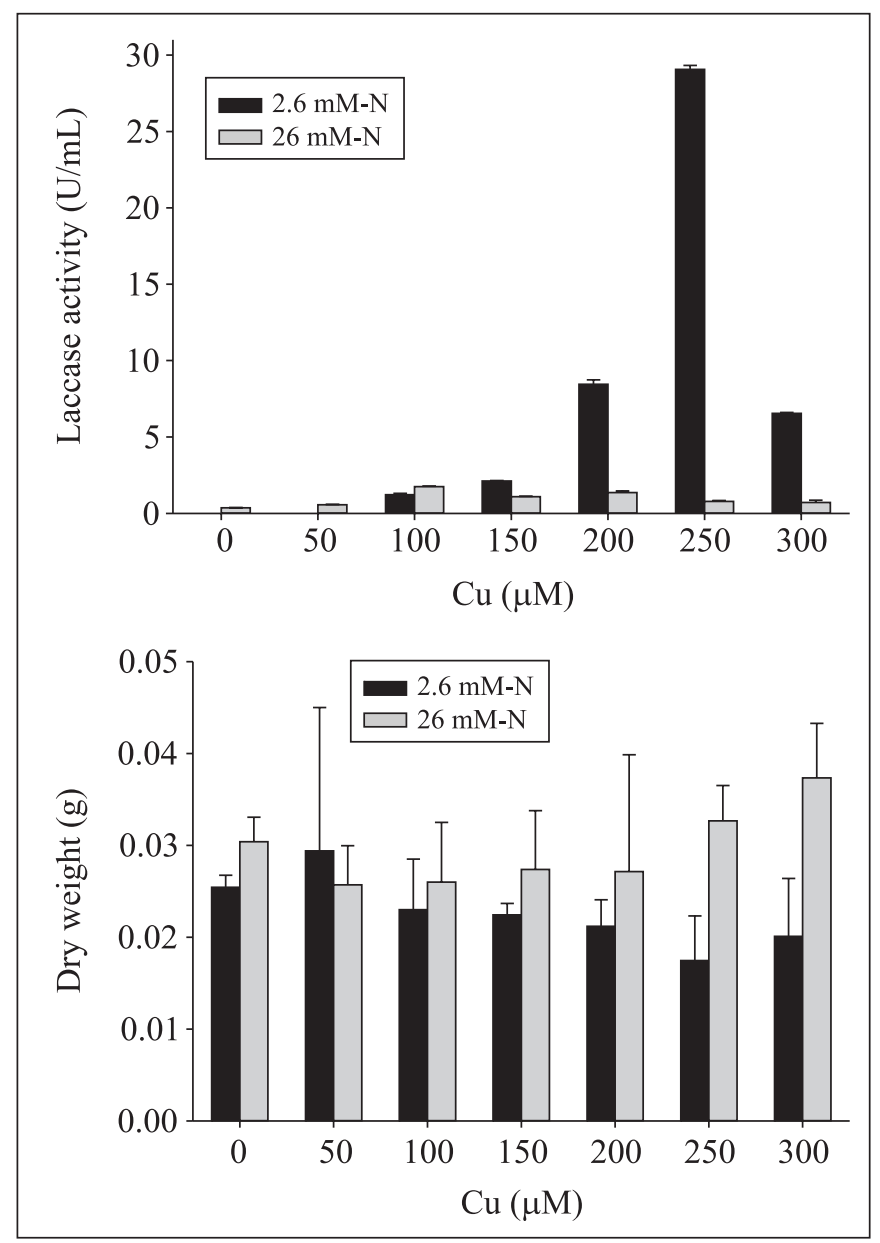

Figure 1. Laccase activity (A) and mycelium dry weight (B) in L. edodes cultures with two levels of nitrogen and seven levels of copper sulphate. Bars: standard deviation. 
in the further steps of this investigation. In order to compare the effect of the remaining compounds on laccase activity a time course experiment was carried out. The cultures receiving vanillin showed the highest protein concentration (Fig. 2A) while those grown in medium with 3 hydroxybenzoic acid showed the lowest laccase activity reaching a maximum of 3.5 $\mathrm{U} / \mathrm{mL}$ extract at day 21 (Fig. 2B). Vanillin exhibited a little influence on laccase activity, showing two peaks of activity on days 21 and 30. The control without any putative inducer started with low laccase activity (Fig. 2B), then it increased from day 10, reaching $67 \mathrm{U} / \mathrm{mL}$ at day 21 . Laccase activity on those cultures decreased on day 23 and started increasing again until day 30 . Ammonium tartrate was the compound that exerted the most expressive positive influence on laccase activity (Fig. 2B). The cultures with ammonium tartrate expressed more laccase activity than the other treatments exhibiting an increase in activity and reaching a peak of $251 \mathrm{U} / \mathrm{mL}$ filtrate at day 30 . After 30 days of growing the $L$. edodes cultures with ammonium tartrate produced the highest amount of mycelium ( $36 \mathrm{mg}$, Fig. 2C). The control treatment showed the lowest value of mycelium dry weight $(23 \mathrm{mg})$ and the two others showed an intermediate value (26.5 mg).

In order to investigate whether the addition of these compounds on culture media resulted in synthesis of new laccase isozymes, a native PAGE (polyacrylamide gel electrophoresis) was performed 15 days after inoculation. Native PAGE was carried out using $4 \%$ stacking gel and $7.5 \%$ separating gel at $110 \mathrm{~V}$ with the Mini-Protean II electrophoresis cell (Biorad) in non-denaturing conditions. Proteins bands exhibiting laccase activity stained green with ABTS $(0.03 \% \mathrm{w} / \mathrm{v})$ in $0.125 \mathrm{M}$ acetate buffer, pH 5.0. Native PAGE analysis of $L$. edodes culture media revealed only one band in all treatments (data not shown), which suggests that the effect on laccase activity was not due to new isozymes expression.

\section{DISCUSSION}

Our study demonstrated clearly that LN conditions are required for high laccase activity (Fig. 1A) in the conditions used in this experiment. Nitrogen plays a key role in laccase production, so its optimum concentration in a culture medium where a determined organism is being cultivated must be determined. It is well documented that both the nature and concentration of nitrogen in culture media for growing white rot fungi are essential for laccase production (12). Usually high $\mathrm{N}$ concentrations are required for optimal laccase production (13), although some reports have described increased laccase production in nitrogen limiting conditions $(10,19)$. Copper concentration in culture media had an expressive effect in cultures with low nitrogen concentration rather than the cultures with high nitrogen content (Fig. 1B). Copper is a laccase cofactor which presents four cupric ions

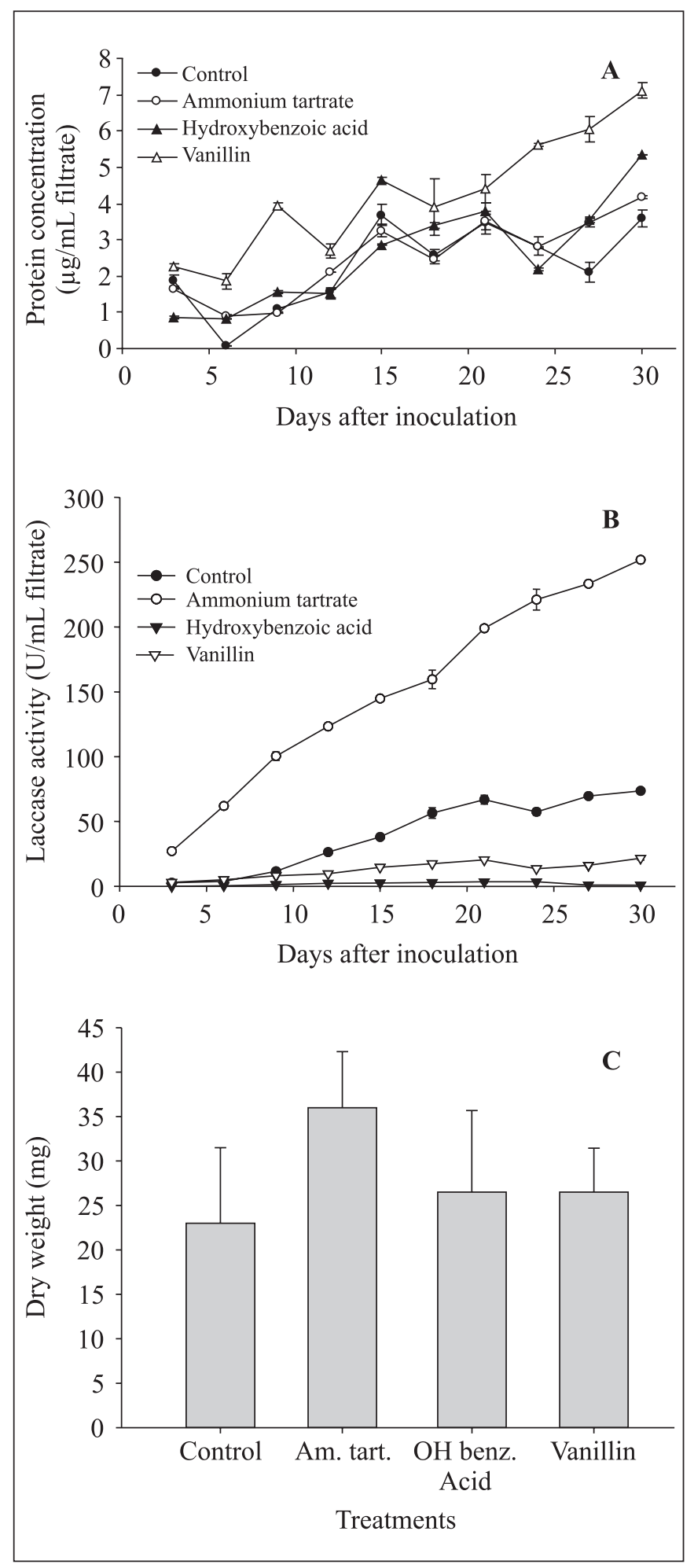

Figure 2. Protein concentration (A), laccase activity (B) and mycelium dry weight $(\mathrm{C})$ of $L$. edodes in cultures containing laccase putative inducers after 30 days of cultivation. Bars: standard deviation. 
each associated with one single polypeptide chain (23) but it also has been proved that this element may play an important role in laccase genes regulation at transcription level as showed in Trametes versicolor (7) Phanerochaete chrysosporium (9), Pleurotus ostreatus (18) and Coriolopsis rigida (20). The 250 $\mu \mathrm{M} \mathrm{Cu}$ provided the highest laccase activity in LN cultures, which is in accordance to the findings for other fungi, like $T$. versicolor $(400 \mu \mathrm{M})(7)$, P. ostreatus $(1.0 \mathrm{mM})(3)$ and $V$. volvacea $(200 \mu \mathrm{M})(6)$.

Among all compounds tested, only ammonium tartrate effectively had an inductive effect on laccase production by $L$. edodes, as shown in Fig. 2A. Vanillin repressed laccase activity when compared with control, and hydroxybenzoic acid almost repressed completely laccase activity. Several studies $(23,26)$ suggest that one of the most important role of laccases is the protector effect against phenolic compounds produced as a result of lignin degradation, which would be toxic for the organism. However, the fact that no laccase induction was detected in those previous experiments using phenolic compounds makes it clear that the role of laccase in ligninolysis and protection still remains to be fully elucidated.

In the present study, it was used hydroxybenzoic acid, which is an aromatic compound and a lignin precursor, but instead of an induction it was observed a decrease in laccase activity (Fig. 2B), although the growth had been stimulated in comparison with the control treatment (Fig. 2C). This compound enhanced laccase activity in Marasmius quercophilus 1.8-fold (11) and also led to a new isozyme synthesis. Sethuraman et al. (21) reported that both growth and laccase production by Ceriporiopsis subvermispora were enhanced with the addition of hydroxybenzoic acid at $1 \mathrm{mM}$ final concentration and the compound inhibited the growth of Cyathus stercoreus although the laccase activity was also increased. An inductive effect of hydroxybenzoic acid in Marasmius quercophilus C30 was reported by Klonowska et al. (14) which also detected new isoforms in presence of this inducer. These differences in the results obtained using this compound as inducer are quite normal if we take into account that the effects of an aromatic compound on laccase activity and growth are dependent on the organism, the concentration and time of addition of the individual compound as well as the culture media used $(6,21)$.

Collins and Dobson (7) investigated the effect of five ammonium tartrate concentrations $(0.5$ to $54.3 \mathrm{mM})$ in $T$. versicolor cultures and detected not only an increase in laccase activity, but also an increase in levels of $l c c$ mRNA. Those data suggested that in $T$. versicolor the lcc gene expression is regulated at the transcriptional level by nitrogen.

Among all the putative inducers tested, only ammonium tartrate was able to increase laccase activity in comparison to the control treatment. The native-PAGE experiment suggests that the stimulating effect was not due to new isozymes expression, but because of an increase of the expression of the constitutive isoform. Investigations leading to the optimization of laccase activity may be useful, since it can help to increase the production of this biotechnologically important enzyme. In further experiments, other putative inducers must be tested and their effect on laccase activity investigated, as well as the effect of increasing laccase activity on the degradation of natural substrates like wood and sawdust.

\section{CONCLUSIONS}

The results show that the best nitrogen concentration to increase laccase activity in L. edodes liquid culture was $2.6 \mathrm{mM}$ $\mathrm{N}$ added as L-asparagine, and the best copper concentration was $250 \mu \mathrm{M}$. Ammonium tartrate increased laccase activity, and the other putative inducers added to the medium inhibited laccase activity. In all treatments only one laccase isozyme was detected, which suggests that the addition of the compounds did not lead to new isozyme synthesis.

\section{RESUMO}

\section{Seleção de indutores para produção de lacase por Lentinula edodes}

Lacases são enzimas envolvidas na degradação da lignina e produzidas por diversos organismos. Devido à sua baixa especificidade por substratos, seu potencial para utilização em aplicações biotecnológicas tem sido objeto de investigação. A adição de indutores de lacases ao meio de cultivo de microrganismos aumenta a produção dessas enzimas, facilitando sua purificação e utilização. Este trabalho teve como objetivo investigar o efeito de alguns compostos utilizados como indutores de lacases em fungos na produção destas enzimas por Lentinula edodes (shiitake). Previamente a utilização de indutores, foi selecionado um meio de cultura para a produção de lacases por shiitake, utilizando-se duas concentrações de $\mathrm{N}$ $(2,6 \mathrm{mM} \mathrm{e} 26 \mathrm{mM})$ e sete de $\mathrm{Cu}(0,50,100,150,200,250$ e 300 $\mu \mathrm{M})$. O meio no qual maior atividade de lacases foi detectada continha 2,6 mM N e $250 \mu \mathrm{M}$ de $\mathrm{Cu}$. Posteriormente, ao meio selecionado foram adicionados ácido gálico $(1 \mathrm{mM})$, catecol $(1 \mathrm{mM})$, tartarato de amônio $(55 \mu \mathrm{M})$, ácido hidroxibenzóico $(1 \mathrm{mM})$ e vanilina $(1 \mathrm{mM})$. Os dois primeiros compostos inibiram completamente a atividade de lacases por shiitake, e um experimento com os restantes foi conduzido por 30 dias. Apenas as culturas com tartarato de amônio apresentaram atividade de lacase maior que o tratamento controle, alcançando $251 \mathrm{U} / \mathrm{mL}$ de extrato após 30 dias de cultivo. Um gel de atividade (native PAGE) exibiu apenas uma banda, sugerindo não haver produção e isozimas.

Palavras-chave: lacase, shiitake, indutores de lacase 


\section{REFERENCES}

1. Alexandre, G.; Zhulin, I.Z. Laccases are widespread in bacteria. Tibtech, 18, 41-42, 2000.

2. Ardon, O.; Kerem, Z.; Hadar, Y. Enhancement of laccase activity in liquid cultures of the ligninolytic fungus Pleurotus ostreatus by cotton stalk extract. J. Biotechnol., 51, 201-207, 1996.

3. Baldrian, P.; Gabriel, J. Copper and cadmium increase laccase activity in Pleurotus ostreatus. FEMS Microbio. Lett., 206, 69-74, 2002.

4. Buswell, J.A.; Cai, Y.; Chang, S.T. Effect of nutrient nitrogen and manganese on manganese peroxidase and laccase production by Lentinula (Lentinus) edodes. FEMS Microbiol. Lett., 128, 81-88, 1995.

5. Chang, S.T.; Miles, P.G. Recent trends in world production of cultivated mushrooms. Mushroom J., 503, 15-18, 1991.

6. Chen, S.; Ma, D.; Ge, W.; Buswell, J.A. Induction of laccase activity in the edible straw mushroom, Volvariella volvacea. FEMS Microbiol. Lett., 218, 143-148, 2003.

7. Collins, P.J.; Dobson, A.D.W. Regulation of laccase gene transcription in Trametes versicolor. Appl. Environ. Microbiol., 63, 3444-3450, 1997.

8. Dhawan, S.; Kuhad, R.C. Effect of amino acids and vitamins on laccase production by the bird's nest fungus Cyathus bulleri. Bioresour. Technol., 84, 35-38, 2002.

9. Dittmer, J.K.; Patel, N.J.; Dhawale, S.W.; Dhawale, S.S. Production of multiple laccase isoforms by Phanerochaete chrysosporium grown under nutrient sufficiency. FEMS Microbiol. Lett., 149, 65-70, 1997.

10. Eggert, C.; Temp, U.; Eriksson, K.E.L. The ligninolytic system of white rot fungus Pycnoporus cinnabarinus: Purification and characterization of the laccase. Appl. Environ. Microbiol., 62, 1151$1158,1996$.

11. Farnet, A.-M.; Tagger, S.; Le Petit, J. Effects of copper and aromatic inducers on the laccases of the white-rot fungus Marasmius quercophilus. Plant Biol. Pathol., 322, 499-503, 1999.

12. Galhaup, C.; Wagner, H.; Hinterstoisser, B.; Haltrich, D. Increased production of laccase by the wood-degrading basidiomycete Trametes pubescens. Enzyme Microb. Technol., 30, 529-536, 2002.

13. Gianfreda, L.; Xu, F.; Bollag, J.-M. Laccases: a useful group of oxidoreductive enzymes. Bioremediation J., 3, 1-25, 1999.
14. Klonowska, A.; Petit, J.L.; Tron, T. Enhanced of minor laccases production in the basidiomycete Marasmius quercophilus C30. FEMS Microbiol. Lett., 200, 25-30, 2001.

15. Mayer, A.M. Polyphenol oxidases in plants-recent progress. Phytochemistry, 26, 11-20, 1987.

16. Min, K.-L.; Kim, Y.-H.; Kim, Y.W.; Jung, H.S.; Hah, Y.C. Characterization of a Novel Laccase Produced by the Wood-Rotting Fungus Phellinus ribis. Arch. Biochem. Biophys., 392(2), 279-286, 2001

17. Nyanhongo, G.S.; Gomes, J.; Gübitz, G.; Zvauya, R.; Read, J.S.; Steiner W. Production of laccase by a newly isolated strains of Trametes modesta. Bioresour. Technol., 84, 259-263, 2002.

18. Palmieri, G.; Giardina, P.; Bianco, C.; Fontanella, B.; Sannia, G. Copper induction of laccase isoenzymes in the ligninolytic fungus Pleurotus ostreatus. Appl. Environ. Microbiol., 66, 920-924, 2000.

19. Pointing, S.B.; Jones, E.B.G.; Vrijmoed, L.L.P. Optimization of laccase production by Pycnoporus sanguineus in submerged liquid culture. Mycologia, 92, 139-144, 2000

20. Saparrat, M.C.N.; Guillén, F.; Arambarri, A.M.; Martínez, A.T.; Martínez, M.J. Induction, isolation, and characterization of two laccases from the white rot basidiomycete Coriolopsis rigida. Appl. Environ. Microbiol., 68(4), 1534-1540, 2002.

21. Sethuraman, A.; Akin, D.E.; Eisele, F.G.; Eriksson, K.-E.L. Effect of aromatic compounds on growth and ligninolytic enzyme production of two white rot fungi Ceriporiopsis subvermispora and Cyathus stercoreus. Can. J. Microbiol., 44, 872-885, 1998.

22. Thomas, B.R.; Yonekura, M.; Morgan, T.D.; Czapla, T.H.; Hopkins, T.L.; Kramer, K.J. A trypsin-solubilized laccase from pharate pupal integument of the tobacco hornworm Manduca sexta. Insect Biochem., 19, 611-622, 1989

23. Thurston, C.F. The structure and function of fungal laccases. Microbiology, 140, 19-26, 1994.

24. Tokimoto, K.; Fukuda, M.; Tsuboi, M. Effect of the physical properties of Lentinula edodes bedlogs on fruiting body production. Mycoscience, 39, 217-219, 1998.

25. Yaropolov, A.I.; Skorobogat'ko, O.V.; Vartanov, S.S.; Varfolomeyev, M.W. Laccase properties, catalytic mechanism, and applicability Appl. Biochem. Biotechnol., 49, 257-280, 1994.

26. Youn, H.-D.; Hah, Y.C.; Kang, S.-O. Role of laccase in lignin degradation by white-rot fungi. FEMS Microbiol. Lett., 132, 183-188, 1995. 